\title{
Angklung Inspired Engineering Design Course
}

\author{
Estiyanti Ekawati $^{\mathrm{a}, 1}$, Eko Mursito Budi ${ }^{\mathrm{a}}$, Ardhana Putra ${ }^{\mathrm{a}}$, \\ Manik Mahachandra ${ }^{a}$, Augie Widyotriatmo ${ }^{a}$ \\ ${ }^{a}$ Faculty of Industrial Technology, Bandung Institute of Technology \\ J1. Ganesa 10, Bandung 40132, Indonesia \\ esti@tf.itb.ac.id
}

\begin{abstract}
Angklung is a traditional musical instrument of Indonesia that has been existed since the Hindu era. The whole parts of this instrument is made from bamboo and tied by rattan cord. For centuries, artisans have perfecting the craftsmanship of angklung based on inherited wisdom. Since 1968, angklung has been regarded as an official instrument for music education in Indonesia. More than 45 years later, ITB initiated a course of "Introduction to Engineering Design" for the first year students. Angklung production was chosen as one challenge to convey various aspects of engineering design, such as comprehension of science principles, capability to design and to manufacture and sensitivity to societal contexts. This paper presents how the challenge reveals multidisciplinary science and engineering concepts including acoustics, instrumentation, and decisionmaking. The stages of course planning, implementation, and evaluations were thoroughly analyzed leading to the recommendation of improvement at achieving the students' outcomes at the next academic year.

Index Terms - engineering education, angklung, local content.
\end{abstract}

\section{The Engineering Skills}

Today's globalization of engineering ideas, productions and expertise had alerted the engineering educators to produce competitive graduates by redesigning the teaching and learning environment. Redish and Smith [1] urged the engineering education to address the concerns by not only focus on the comprehension of engineering concepts, such as mechanics, dynamics, mathematics, and technology, but also to develop the skills associated with learning to apply this knowledge in real-world situations. This demanded not only skills of creativity, teamwork, and design, but also in communication, ethics and lifelong learning.

These soft skills have gained acceptances across the global engineering tertiary educations. For example, for more than five years ABET, an international accrediting agency, stated that an engineering program must have program educational objectives that are consistent with the mission of the institution, and the needs of the program's various constituencies. In order to attain the objectives, the program must train the students to achieve eleven outcomes, as listed in Table 1, plus any additional outcomes that may be articulated by the program [2]. The list shows that the outcomes (e)-(j) are the soft skills and sensitivity to community contexts that are required to excel in the real workplace as stated by Ref. [1].

In parallel fashion, the Directorate General of Tertiary Education in Indonesian, also recently endorsed the Indonesian Qualification Framework that defined the learning outcomes for all Indonesian tertiary education [2], of which also coherent with those stated by ABET and other international accrediting agency.

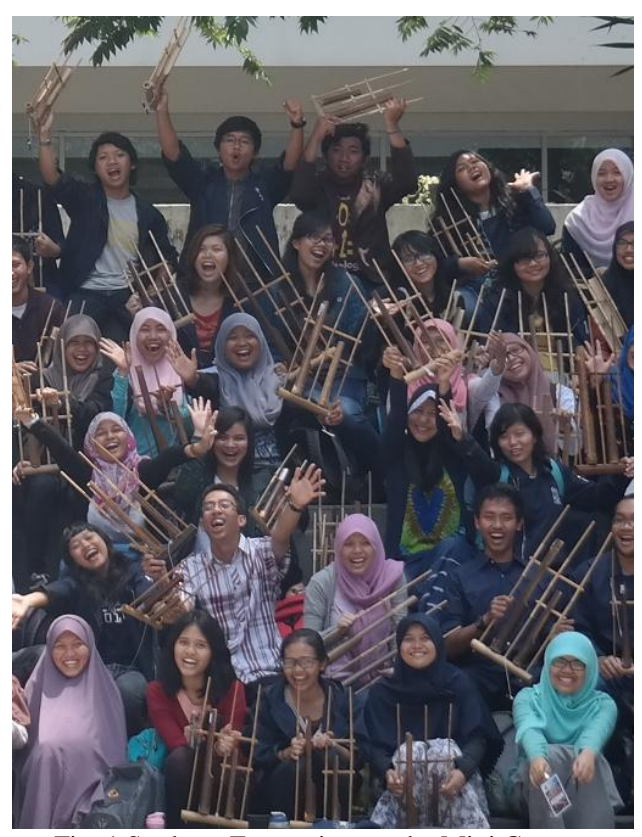

Fig. 1 Students Expressions at the Mini Concert of Angklung Production Challenge.

Table 1 List of ABET Student Outcomes [2]

\begin{tabular}{|l|l|}
\hline No & \multicolumn{1}{|c|}{ Student Outcome } \\
\hline (a) & $\begin{array}{l}\text { An ability to apply knowledge of mathematics, science, and } \\
\text { engineering }\end{array}$ \\
\hline (b) & $\begin{array}{l}\text { An ability to design and conduct experiments, as well as to } \\
\text { analyze and interpret data }\end{array}$ \\
\hline (c) & $\begin{array}{l}\text { An ability to design a system, component, or process to } \\
\text { meet desired needs within realistic constraints such as } \\
\text { economic, environmental, social, political, ethical, health } \\
\text { and safety, manufacturability, and sustainability }\end{array}$ \\
\hline (d) & An ability to function on multidisciplinary teams \\
\hline (e) & $\begin{array}{l}\text { An ability to identify, formulate, and solve engineering } \\
\text { problems }\end{array}$ \\
\hline (f) & An understanding of professional and ethical responsibility \\
\hline (g) & An ability to communicate effectively \\
\hline (h) & $\begin{array}{l}\text { The broad education necessary to understand the impact of } \\
\text { engineering solutions in a global, economic, environmental, } \\
\text { and societal context }\end{array}$ \\
\hline (i) & $\begin{array}{l}\text { A recognition of the need for, and an ability to engage in } \\
\text { life-long learning }\end{array}$ \\
\hline (k) & $\begin{array}{l}\text { An ability to use the techniques, skills, and modern } \\
\text { engineering tools necessary for engineering practice. }\end{array}$ \\
\hline
\end{tabular}


These considerations also affected Bandung Institute of Technology (Institut Teknologi Bandung, ITB). Being an institute of technology residing in Indonesia and having several ABET accredited programs (as in 2014: Electrical Engineering, Ocean Engineering, Engineering Physics, Chemical Engineering), ITB was bound to attain both the outcomes as defined by ABET as well as those by the Indonesian Qualification Framework.

This calls for the fresh approaches for building effective engineering teaching and learning environments. A good grasp of the facts, equations, and even concepts are only the beginning. What matters more is that the students learn how to use that knowledge in authentic contexts [1]. The challenge is how to instill that capability to the ITB's first year undergraduate students.

\section{The Problem of Being First Year Student in ITB}

ITB is fortunate enough for easily recruiting bright students of the countries. However, similar to what happened in USA as the described in the CAEE report [2], entering students interested in engineering often have limited knowledge of engineering. Many of these students expressed their enjoyment of and success in high school math and science. These motivated them to choose engineering majors in tertiary studies. However, in reality these students had little exposure to engineering during the secondary schools.

Many of the current $12^{\text {th }}$ grade students in Indonesia spent most of the time being heavily drilled to memorize formulas in order to pass the final high school evaluations as well as the university entrance tests. There was not much time left to foster their engineering through their own individual or group projects.

When these students were admitted to ITB, they became the students of the division/schools for the first year's common preparation program. Here they had common math, science and general courses. The decision whether they can enter their chosen program at the second year is based on the program's capacity. If their first year grade is below the passing grade, they have to settle for the second or third chosen programs. Therefore, the first year in ITB is another fierce competition to get entry to some favorite programs.

The class size at the first year program was determined by the availability of lecturers, classrooms and labs. Therefore, the grouping of class participants varied across courses. At every first year class they attended, every student might meet different classmates. Some might found this opportunity to make new friends and socialize. But some other might choose to stick with old schoolmates. Those whom the only representative of school or region may became isolated due to the stress of competition. At this situation, the communication and teamwork skills that are vital to develop an integrated engineering work can only be nurtured through specifically designed teaching and learning environment.

\section{Introduction to Engineering Design Course}

Atman et.al [4] reported that most engineering programs introduce the engineering concepts way too late, after $3^{\text {rd }}$ or $4^{\text {th }}$ semester. This was after which students were drilled with the basic science, math and general courses. Similar problem also happen in FIT ITB. During these semesters students may have forget how to combine both hard and social skills to succeed engineering projects.

To address the problem, ITB initiated the introduction of engineering concepts and skills early on for first year undergraduate students. This was through the Introduction to Engineering Design (IED) I and II courses in the academic year 2013-2014. The courses were provided at the first and the second semester respectively, each of 2 credit hours. The aim of this course was to motivate the students in engineering learning. The theme of first semester was the minds-on engineering. This covered the role of engineering and design in society, engineer as a profession, skills required in engineering, key element of engineering analysis, steps in solving problems, concept of energy, conversion and conservation, and some examples of engineering discipline as well as ethics in engineering. The students were introduced to these concepts through live lectures, video lectures, group discussions, essays writing and online quizzes. The theme of the second semester was the hands-on engineering group and individual projects, based on the theme introduced in the first semester.

The course management was delegated to 6 clusters of schools/divisions in ITB. The students of Faculty of Industrial Technology (FIT), the School of Life Sciences (SLS) and the School of Pharmacy (SP) were grouped in Cluster II. The FIT lecturers were from Engineering Physics (EP), Chemical Engineering (CE) and Industrial Engineering (IE) programs. The SLS lecturers were from Microbiology and Bio Engineering programs, while the SP lecturers were from the Pharmacy Science and Technology and the Clinical and Community Pharmacy programs. This interesting grouping enforced Cluster II lecturers to consider a main theme that highlight the multidisciplinary aspect of engineering approach. Finally, the lecturers agreed on the theme "The Local Renewable Energy Sources: Biomass". This theme highlighted the importance of life science approaches in managing the biomass sources, of which pharmaceutical discipline also benefitted due to the community pharmacology point of view. The CE lecturers focused on combustion and gasification of biomass, EP discussed energy conversion, distribution and control, and finally IE presented the management of engineering process. Throughout the first semester, all lecturers covered the common contents of engineering design and the above aspects of main themes, with highlights on local content and the economic value of biomass based energy generating system.

As for the engineering hands-on at second semester, developing a renewable energy system was considered too complex and not economical for first year students to cover in 2 credit hours. Therefore, the lecturers considered alternative design challenges that covered some procedures of energy transfer and conservation, and also sent strong local content messages.

These design challenges were:

1. The charcoal production (Pyrolysis process)

2. The tempe production (Fermentation process)

3. The angklung production (Acoustical system) 
The pyrolysis and the fermentation processes were the known method to conserve and to extract energy of biomass product. The challenges were to run the processes with unconventional materials. For example, students were challenged not to use soy beans to make tempe, but were encouraged to use other plants. The production of angklung focused on the phenomenon of sound propagation as form of energy transfers. It regarded acoustical system as potential energy source in the future. Altogether, these challenges highlighted the engineering aspects of energy conservation and generation of local biomass system.

Form this point onwards, this paper focuses on the planning, implementation and evaluation of angklung design challenge, and its effect to the students learning in the Introduction to Engineering Design II course at Cluster II. The charcoal and tempe challenges are reported in separate documents.

\section{A. How Angklung Works}

Angklung is a native musical instrument that has been existed since the Hindu era in Indonesia $\left(7^{\text {th }}-13^{\text {th }}\right.$ centuries). In early time, angklung was played in many traditional ceremonies, such as celebrating harvesting seasons and worshipping the nature's goddess. Due to the components arrangement and the necessity to play in-group, angklung was also associated with principles of harmonious relationship with nature and society. Towards the modern days, angklung evolved from traditional musical instruments played with interlocking percussive style into modern melodious instrument capable of playing complex musical arrangement. Angklung was further acknowledged as an official instrument for musical education in Indonesia at 1968 [5].

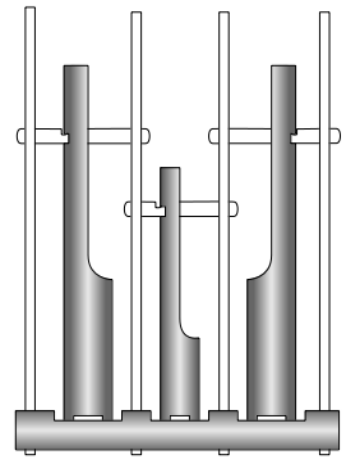

(a)

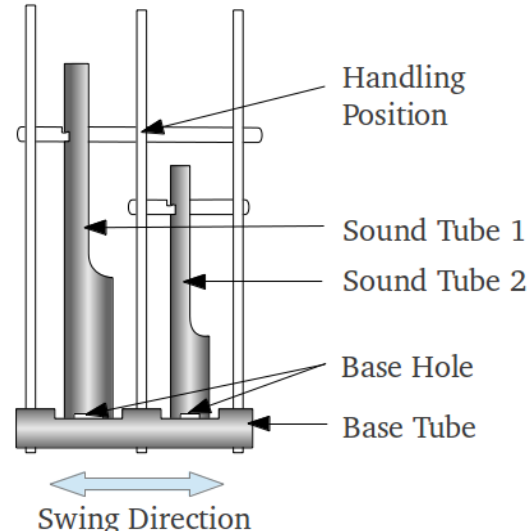

(b)

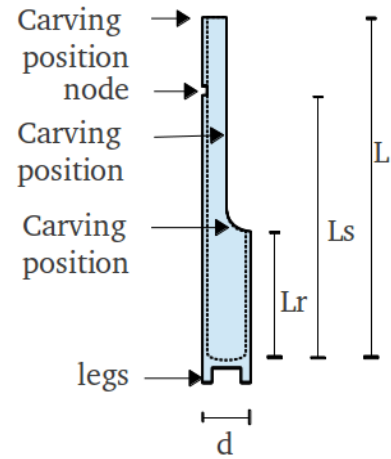

(c)

Fig. 2 Angklung Schematic [6], [7]

\section{The Angklung Design Challenge}

This long history is made possible by the simplicity and flexibility of angklung structure. As shown in Figs. 2a and $2 \mathrm{~b}$, the instrument is made from two-or-three bamboo tubes attached to a bamboo frame. Each tube has a closed bottom and an open top. The open part is carved to a shape shown in Fig. 2c. The top part is attached to the frame. The bottom can swing, but bounded by small legs that fit loosely into holes at the base tube. The instrument is played by holding the frame handle in one hand and shaking the frame base by other hand. As the tube legs strike the base holes, it produces a standing wave of sound that resonates through the tube's wall and air inside the tube as illustrated in Fig. 3. This produces a repeating struck sound with a particular 'pitch', or better known as a 'note' [6].

The bamboo tube is tuned by carving the points as shown in Fig.2.c such that the note produced when the tube is struck is the same with the note produced when the tube is blown. The node position is where the hole is made to attach the tube on the frame. At the other end, the tube should swing across the hole at the base tube such that it produces optimum strikes This determine the clarity and loudness of the struck sound [7].
Since one angklung only produces one note, several angklungs are required to play a full octave. For example, one set of angklung in diatonic octave consists of notes $\mathrm{C} 3$, $\mathrm{C}^{\#}, \mathrm{D} 3, \mathrm{D} 3^{\#}, \mathrm{E} 3, \mathrm{~F} 3,3^{\#}, \mathrm{G} 3, \mathrm{G} 3^{\#}, \mathrm{~A} 4, \mathrm{~A} 4^{\#}, \mathrm{~B} 4, \mathrm{C} 4$. Here, A4 has the same pitch with standard ' $A$ ' note with the main frequency at $440 \mathrm{~Hz}$. What distinguishes the sound of angklung with other musical instruments is 'timbre'. Timbre is represented by unique frequency spectrum of the instrument. Hence, the timbre is determined by the tube dimension and shape, the resonation between tubes and the strike quality [6].

The type and the shape of bamboo, as well as the preservation method determine the acoustical properties (pitch, timbre, clarity and loudness) and the instrument longevity and purpose. High quality musical angklungs should be made of certain species of bamboo (local names: 'black', 'tali' and 'gombong'), preferably those that grow in dry climate [7].

The bamboos are harvested in dry season and further air-dried for 4-6 months. This procedure ensures the bamboo achieves its final dimension, so that the produced note will not stray away with time. It is also ensures that the material do not attract bugs that eat into the bamboo's wall [7]. 


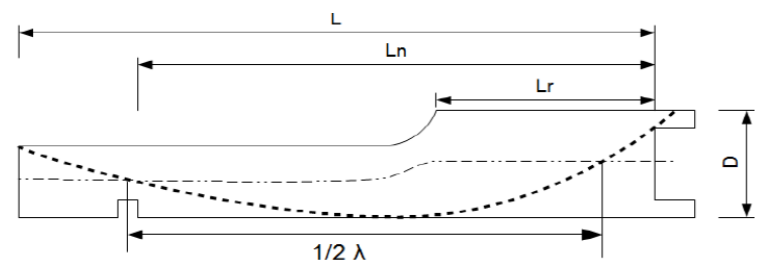

Fig. 3.a Standing Wave in Sound Tube [5]

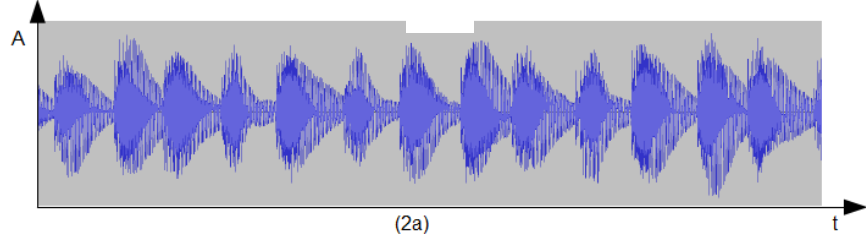

Fig. 3.b Angklung Strike Sound Pattern [5]

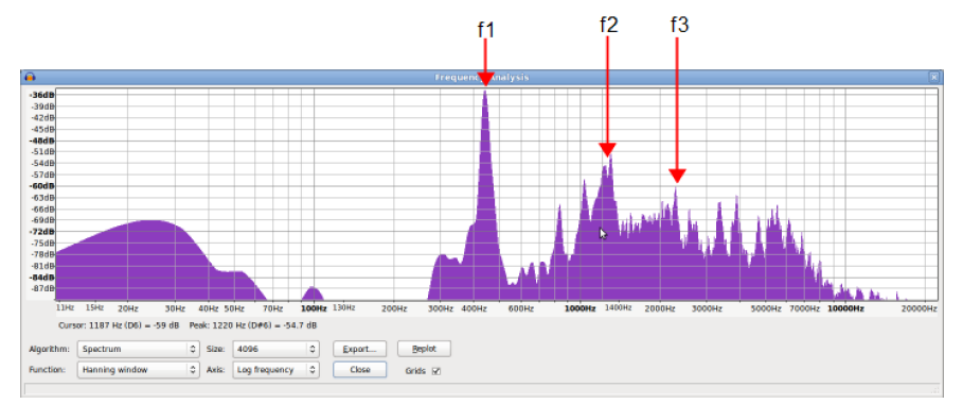

Fig. 3.c Angklung Frequency Spectrum [5]

\section{B. The Engineering Challenge and Learning Plan}

The above description shows that angklung production is a rigorous engineering process. Nevertheless, due to limited documented studies about bamboo preservations and angklung acoustical properties, this art of production have been transferred across generations mostly through long term, on-the-job training fashion. Inheriting the skills of angklung master, such as detecting the coherence between struck note and blow note only by hearing, was a long process since it requires sensitivity to timbre and pitch.

These conditions motivated the challenge for FIT students in Cluster II. In this challenge, students were provided with acoustical theories and angklung production principles. Then they were given the opportunity to handle the bamboo tubes and manually tune them with supports of modern musical tuners, and also the opportunities to collaborate in teams to produce a complete set of angklung.

The learning objectives of this challenge were therefore:

1. To identify angklung material and acoustical properties

2. To practice the angklung quality assurance by utilization of acoustical measuring instruments

3. To practice the teamwork and communication skills in small and large groups in defining production purposes and conducting effective production process

4. To recognize the societal contexts of angklung

Therefore the learning outcomes were the items (a)-(d), (f)-(h) and (k) listed in Table 1.

This challenge was given to six classes FIT students. Each class consists of around 62 students, and they were set into 16 groups. Each group produced two units of angklung, therefore one class produced two octaves (32) angklungs. The student grades were determined by the quality of class production process, in addition of the individual quiz and mid semester test grades.
The class was graded based on

1. Production criteria agreed by the whole class member

2. Angklung's quality based on the agreed criteria

3. Organization and teamwork of production process demonstrated by design production reports

Table 2 Learning Plan of Angklung Production

\begin{tabular}{|c|l|}
\hline Week & \multicolumn{1}{c|}{ Activities } \\
\hline 1 & $\begin{array}{l}\text { Lecture \#1: Review of engineering design process, } \\
\text { The past, present and the future of acoustical systems }\end{array}$ \\
\hline 2 & $\begin{array}{l}\text { Lecture \#2: Mechanical waves, sound and hearing } \\
\text { phenomena, acoustical properties of musical instruments }\end{array}$ \\
\hline 3 & $\begin{array}{l}\text { Workshop \#1: Angklung material properties, } \\
\text { Introduction and calibration of musical tuner and acoustical } \\
\text { analysis } \\
\text { Report \#1: Group data, angklung dimensional and } \\
\text { condition data, digital tuner and acoustical analyzer } \\
\text { calibration data }\end{array}$ \\
\hline 4 & $\begin{array}{l}\text { Lecture \#3: Angklung philosophy and acoustical properties, } \\
\text { Production SWOT analysis, objectives and strategies } \\
\text { Report \#1: production SWOT analysis, objectives and } \\
\text { strategies }\end{array}$ \\
\hline 5 & $\begin{array}{l}\text { Workshop \#2: Angklung tuning } \\
\text { Report \#2: Data and analysis of angklung 's note before } \\
\text { and after tuning }\end{array}$ \\
\hline 6 & $\begin{array}{l}\text { Workshop \#3: Angklung assembly } \\
\text { Report \#3: Data and analysis of assembly process and } \\
\text { angklung quality } \\
\text { Test \#1: Online Quiz } \\
\text { Workshop \#4: Angklung mini concert, finalization of } \\
\text { angklung production }\end{array}$ \\
\hline 7 & \begin{tabular}{l} 
Test \#2: Mid Semester Test \\
\hline
\end{tabular} \\
\hline 5 & \\
\hline 5
\end{tabular}

This enforced the whole class to collaborate and to clear out the isolation between students throughout the production process. The process was guided through eight weeks learning plan as listed in Table 2. 


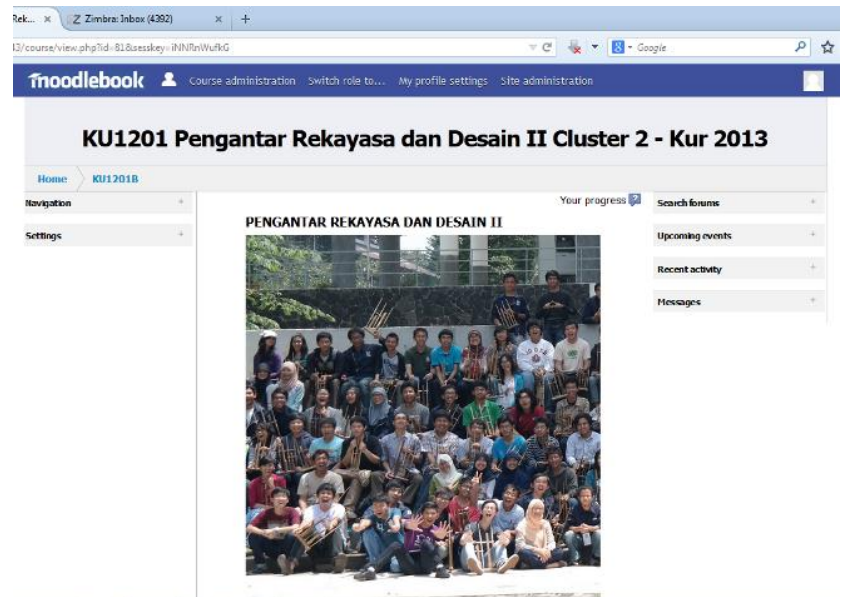

Fig. 4 Snapshot of E-learning Web Site

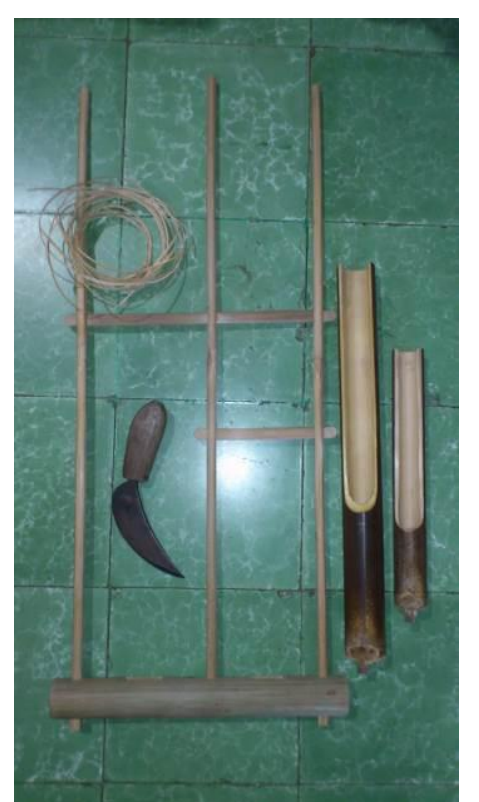

Fig. 5 Angklung Materials Provided for Students

\section{Implementation}

During the semester, there were two challenges for FIT students, the angklung production and the charcoal production. Therefore the classes were grouped into two batches. The first batch carried out the angklung challenge during first 8 weeks while the other carried out the charcoal challenge. At week 9 onwards, these batches went on to the other challenge.

The angklung-learning plan spanned eight weeks alternating between lectures and workshops. All official activities were scheduled for two credit hours per week, simultaneously in all six classes. Students may need to complete the unfinished tasks, collaborate in groups and write reports after class, within the allocated credit hours.

The student outcomes were pursued through the following learning media:

\section{A. Lectures}

The lectures provided the theoretical bases for angklung production. As listed in Table 2, the topics include the review of engineering design process, the past, present and the future of acoustical systems, mechanical waves, sound and hearing phenomena, acoustical properties of musical instruments, angklung philosophy and acoustical properties, and also production SWOT analysis, objectives and strategies. This was a team-teaching task, of which four EP lecturers taught acoustical aspects and one IE lecturer taught production aspects in rotational fashion. One invited speaker brought his team and taught the angklung tuning and assembly procedure simultaneously in three classes. Three lecturers were assigned as official class advisors to facilitate the whole production process. Here the students learnt to appreciate the multidisciplinary aspects of angklung production. They also learnt that mastering each aspect requires continued education or job experience, hence instilling the concept of lifelong learning.

\section{B. Access to Learning Materials}

The course handouts, group lists, class/workshop schedules, notifications, discussion forums, quizzes and report submissions were provided through e-learning site as shown in Fig. 4. The students were given access to download the materials, participate in class discussion forum, submit reports and run the time-constrained online quiz. Videos of step-by-step angklung making were also produced and provided free for download by students. Here they learnt to utilize information technology to access and to share information and to work individually and in group in timely manner.

\section{Workshop Materials and Measuring Instruments}

All groups received four sets of angklung material and one carving knife. As shown in Fig. 5, each set consists of two sound tubes (these tubes were carved into shape, but still out of tune), one frame and one rattan rope. Each group was assigned two notes. For one note, they had two material sets, so they could use one set for experimenting and submit other set as final product. These final products would be assembled into a complete set of angklung as class product. Therefore, the class should agree on the note distribution among groups. Group with students who has good musical hearing were encouraged to handle high notes that difficult to tune.

The group tools consisted of one hand phone installed with digital tuner application and one laptop computer installed with audio editor software. All applications were open source software and easily downloaded through internet connection. Since not all students may have the required own gadgets, it was the class responsibility to ensure all group had the required tools by gadget lending.

Here the students learnt that the individual and group performances would determine the class performance. Therefore they all had the responsibility to maximize the class's grade during the challenge, either by sharing their musical, gadget or organization skills.

\section{Workshops}

Three workshops were conducted in line with the production phase. Throughout the workshops, lecturers and tutors were deployed to guide the students throughout the process. 
During the first workshop, some member of the groups calibrated the measurement tools with the standard note generator. Therefore they learned the principles of calibration, the quantification of acoustical properties and the standardization of sound quality. The other members collected the materials and compiled the dimensional data. During this process, they sensed the texture, solidity and sound of the tubes, hence learned to appreciate the process of planting and preserving the bamboo for musical purpose.

Before the second workshop, each class should agree upon the criteria of angklung production, i.e. their potential users, the feature and sound quality, and the SWOT analysis of class production. These determined the base of their class production grade, whether they chose to focus on the appearance of angklung, or on the sound quality.

During the second workshops, they carved the sound tubes at the position shown in fig.2.c, i.e. the top $\left(\mathrm{L}_{\mathrm{n}}\right)$ and sides of bar, also the top of resonant tube $\left(\mathrm{L}_{\mathrm{r}}\right)$. During the carving, they examined the strike sounds properties using digital tuners and audio editors as shown in fig 4. They also observed the changes of frequency spectrum and related the changes with the sound quality as illustrated in fig 5. They learnt to recognize the pitch of blow sound by hearing only. Here, by comparing the blow sound and strike sound, they trained their hearing and gained the sensitivity to timbre and pitch.

The students assembled the tubes in to the frame at the third workshop. They attached the node hole $\left(\right.$ at $\mathrm{L}_{\mathrm{n}}$ ) to the frame handle. They also made holes at the base tube, so the sound tubes could swing and the legs stroke the hole to produce the intended loudness.

After angklungs were completed, all three classes joined in a mini concert at the fourth workshop. On this event, many of them saw musical score and played angklung for the first time. Here they learnt to strike angklung properly and to play together a complete song arrangement. The excitement of playing their own made instrument paid off their hard work of tune and assembly. Their expression after the mini concert is shown in Fig. 1.

After each workshop, students were required to compile group data into a class analysis and report. This enforced them to communicate, delegate tasks and submit group work in time to produce a class report. Feedback to class report was announced at the following week, so they could adjust the group and class dynamics and could provide better report next time. The class grades were based on these reports.

\section{F. Online Quizzes and Mid Semester Tests}

Individual grades were gained through online quizzes and written mid semester tests. The problems were based on the on angklung learning materials and workshops. Students had access to attempt the quiz four times during the period of two weeks before the mid semester tests. On each attempt they had different set of multiple-choice problems, but within the same difficulty level, for 45 minutes. The highest grade was recorded as final online quiz grade. This give them chance to properly learnt and rehearse the material.

The mid semester test consisted of twenty multiplechoice problems and two essays. They had 100 minutes to complete the test. The average of multiple choice grade and essays grade is considered as their mid semester grade.

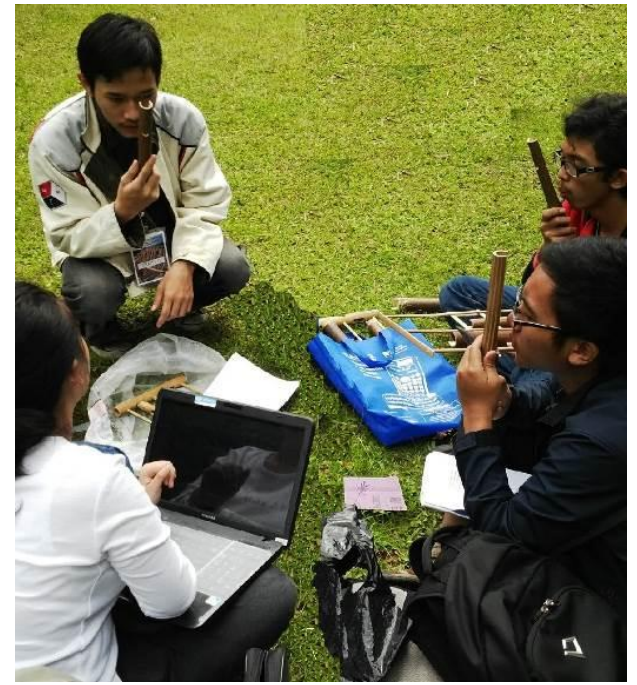

Fig. 6 The Tuning Workshop

\section{Evaluation}

The course planning and implementation were evaluated based on class production grades, class design report grades, individual grades and student questionnaires. The grades represented the faculties' opinion of students/class performances. The questionnaires, on the other hand, represented the students' view of course delivery and organization.

As described earlier, the challenge was done in two batches. The first batch consisted of class 17, 18 and 19 . These classes did the angklung challenge at week 1-8 and went on the charcoal challenge. The second batch consisted of class 15, 16 and 20. These classes did the charcoal challenge first, and went on to the angklung challenge at week $9-16$. All batches were assigned the same groups of lecturers, tutors and design material. Nevertheless, the difference between batches might exist due various situations affecting the class performance. The grade and questionnaires data in relation with lecturer and batches are shown in Tables 3 and 4 . The data analysis is given in the following subsections.

\section{A. Grades}

The class production grade represented the teamwork production results. This was shown through class effort to unify the appearance and quality of their product. These were also compared against the class production analysis, whether they stayed to the agreed strategy, or they changed the strategy as production went on. Class 19 demonstrated the best teamwork by delivering product with relatively uniform appearance, consistent sound quality and strategy. These indicated their effort to communicate and collaborate during and after class to ensure such result.

The comparison between batches was done by statistical student-t test assuming unequal variances with $5 \%$ confidence level. The sample of such analysis is shown in Table 5. The test showed that the mean production grade of Batch I (85.0) is higher than Batch II (83.5). However, due to larger variance (25.0 vs. 6.7$)$, there was no significant difference between these batches. 
Table 3 Students Grade Data

\begin{tabular}{|c|c|c|c|c|c|c|c|}
\hline \multirow{2}{*}{ Class } & \multicolumn{2}{|c|}{ Design Challenge } & \multirow{2}{*}{$\begin{array}{c}\text { Online } \\
\text { Quiz }\end{array}$} & \multicolumn{4}{|c|}{ Mid Semester Test } \\
\hline & Reports & Product & & $\mathrm{MC}$ & Essay 1 & Essay 2 & Total \\
\hline 15 / Lecturer A / Batch II & 85.00 & 85.00 & 91.27 & 12.03 & 6.92 & 5.41 & 71.69 \\
\hline 16 / Lecturer C / Batch II & 88.33 & 85.00 & 91.93 & 12.15 & 7.25 & 4.92 & 72.09 \\
\hline 17 / Lecturer A / Batch I & 87.50 & 80.00 & 86.84 & 12.72 & 7.79 & 6.05 & 76.35 \\
\hline 18 / Lecturer B / Batch I & 82.33 & 85.00 & 86.75 & 12.66 & 7.75 & 5.36 & 75.56 \\
\hline 19 / Lecturer C / Batch I & 77.50 & 90.00 & 87.10 & 12.72 & 7.88 & 5.93 & 74.45 \\
\hline 20 / Lecturer B / Batch II & 80.00 & 80.52 & 91.82 & 12.26 & 7.37 & 4.87 & 72.33 \\
\hline Mean & 83.44 & 84.25 & 89.29 & 12.42 & 7.49 & 5.42 & 73.74 \\
\hline Standard Deviation & 4.27 & 3.65 & 2.63 & 0.31 & 0.38 & 0.49 & 1.98 \\
\hline
\end{tabular}

Table 4 Students Questionnaire Data

\begin{tabular}{|l|l|c|c|c|c|c|}
\multicolumn{2}{|c|}{ Performance index } & 1 & 2 & 3 & 4 & 5 \\
\hline Batch II & Lecturer A & 3.66 & 3.33 & 3.6 & 3.07 & 3.03 \\
\hline Batch II & Lecturer C & 3.06 & 2.63 & 2.96 & 2.67 & 2.68 \\
\hline Batch I & Lecturer A & 3.31 & 2.98 & 3.24 & 2.73 & 2.7 \\
\hline Batch I & Lecturer B & 3.53 & 3.52 & 3.45 & 2.99 & 2.84 \\
\hline Batch I & Lecturer C & 3.32 & 3.06 & 3.3 & 2.86 & 2.69 \\
\hline Batch II & Lecturer B & 3.24 & 3.23 & 3.24 & 3.08 & 2.93 \\
\hline
\end{tabular}

Table 5 Students-t Test Assuming Unequal Variance of Design Production Results

\begin{tabular}{|l|c|c|c|}
\hline \multicolumn{2}{l|}{ Teamwork: Production Result } & \\
\hline & Lecturer A & Lecturer B & Lecturer C \\
\hline Batch I & 80.00 & 85.00 & 90.00 \\
\hline Batch II & 85.00 & 80.52 & 85.00 \\
\hline
\end{tabular}

t-Test: Two-Sample Assuming Unequal Variances

\begin{tabular}{l|c|c|}
\hline & Batch I & Batch II \\
\hline Mean & 85.00 & 83.51 \\
\hline Variance & 25.00 & 6.70 \\
\hline Observations & 3 & 3 \\
\hline Hypothesized Mean Difference & \multicolumn{2}{|c|}{0} \\
\hline$d f$ & \multicolumn{2}{|c|}{3} \\
\hline$t$ Stat & \multicolumn{2}{|c|}{0.46} \\
\hline$P(T<=t)$ one-tail & \multicolumn{2}{|c|}{0.34} \\
\hline$t$ Critical one-tail & \multicolumn{2}{|c|}{2.35} \\
\hline$P(T<=t)$ two-tail & \multicolumn{2}{|c|}{0.68} \\
\hline$t$ Critical two-tail & \multicolumn{2}{|c|}{3.18} \\
\hline
\end{tabular}

The class design report grade also represented the teamwork in compiling data and writing a sound analysis. Class 16 and 17 demonstrated such teamwork, of which each report was written by different person. This demonstrated ability to delegate and share information. On the other hand, high traffic in discussion forum showed that class members contributed by submitting complete group data and analysis. This produced successful analysis of relating angklung formula with the note produced through carve and assembly process. The student-t test showed no significant difference between resulted reports of Batch I and Batch II, due to large variance across class reports.

The interesting fact is that the best angklung set was produced by the class of the lowest report grade. Nonetheless, Class 16 managed to achieve the best production and report grade. This showed the variation of production approaches and priorities on craftsmanship or on analysis. These represent the capability to perform experiments, to use modern tools, to analyze data, to collaborate in team and to communicate in verbal and in writing. These are important aspects of engineering design and deserved their own merit.
The online quizzes represent students' efforts to learn and rehearse the material. The one-tailed student-t test showed that quiz grades of Batch II was significantly higher than those of Batch I. This might indicate that students had already familiar with the quiz environment through the first challenge. However, the opposing result was shown by the mid semester test grade. Batch I had significantly higher grade than Batch II. The grades were consistent through multiple choice and essay problems. This in relation with the design challenge grades suggest that while individual performances in Batch II might have been depleted towards the end of semester, their unity as class had grown better through two challenges.

\section{B. Change of Situations}

What were situations of week 9-16 that affected the significant difference between Batch I and Batch II?

The first situation is exhaustions. This was the first year of 2013 curriculum. All faculties learnt the hard way that the second semester of FIT curriculum required student to attend five courses with labs/workshops including the IED II course. These five labs per week requirement were in full course in week 8-16. The IED II course had cautiously designed the learning plan to maintain the two credit hours load. However, the accumulated load of five courses worn down students' stamina.

The second situation was the limited open space to perform the workshops. The angklung workshop did not require special space other than it separated each group so the struck and blow sounds during the tuning process can be detected clearly and not overlapped with the sound by other groups. The charcoal workshop, on the other hand, required open space that permitted combustion activity and let the smoke clear away without disturbing offices and classes. During week 1-8, such spaces were present in the campus. However, at week 9-16 these spaces were turned to building site, therefore charcoal workshops were moved to much less comfortable location in comparison to the week 1-8.

These conditions affected the student's perception. This was evident in the questionnaire data, since it recorded the student perception for the whole semester, not for each challenges/lecturers.

\section{Student Perception}

Since the questionnaire did not distinguish the student perception for each challenge, and that angklung challenge was a team teaching task, the analyses were not straightforward. Nonetheless, by grouping the indices the pattern gradually appeared.

There were five performance indices shown in Table 4 as follows:

1. The competence of lecturers in delivering materials

2. The commitments of the lecturers

3. The approachability of the lecturers

4. The organization of the course

5. The benefit of attending the course

Therefore the indices (1)-(3) related to the lecturers performance, and (4)-(5) related to the course organization. The acceptable grades was 3.00 and above. Therefore, those grades less than 3.00 in Table 4 were marked red, as serious consideration for improvement. 
By noting that the students' perception of lecturer performances was not determined by one lecturer only, the two-way ANOVA analysis with replication was operated in $5 \%$ confidence level. The performances of each lecturer were used as the replication data of each batch. The indices were also grouped into lecturers' performance (1)-(3) and the course organization (4)-(5). This test showed significant difference between lecturer performance and course organization, but no significant difference between batches. The test also showed no interaction between batches and index group.

The above result was further analyzed using the student$t$ test assuming unequal variances on group (1)-(3). The mean averages were 3.30 and 3.21 and the variances were 0.03 and 0.10 in Batch I and Batch II respectively. This showed no significant difference of student perception towards lecturer performances in all batches. While noting that the Batch II's stamina had depleted, the result showed that students did not depreciate their lecturers.

The same student-t test was operated on group (4)-(5) only to data within the average \pm the standard deviation of each batch. The result was that the mean average of Batch II was significantly higher than Batch I. This might indicate that students of Batch II had significantly better perception towards the course organization. This might due to difference of workshop locations for each batch. The students of Batch I, unfortunately had to perform the charcoal challenge in less favorable location in comparison the angklung challenge. This significantly dropped their appreciation to the overall course organization.

The low grade of aspect (5) indicated that the messages of societal context of engineering design did not go through student perception. By observing back to the beginning of the Engineering Design I at the first semester, this low grade made some sense. Most FIT students wrote that they applied to FIT with the vision of going into modern and established industrial factories after graduation. The development of local product into an economy generating industry was not in their mindset yet. This called for more work on instilling the local and societal context of engineering design to the students. As for comparison, SLS and SP students who did the charcoal and tempe challenges were significantly more appreciative. Their average grades of aspects (4) and (5) are 3.27 and 3.04 respectively.

The low perception grades by Class 16, while on the other hand they demonstrated excellent performance in angklung challenge indicated the need to rectify the delivery and organization of the first challenge.

Despite the exhaustion, the GPA of FIT students of the second semester 2013-2014 were in the second position of all school/divisions in ITB. The random interviews the students revealed that the challenges forced them to develop new friendships and taught them the benefit of teamwork.

\section{Future Works}

Throughout the whole stages of the course, it was obvious that the course performance was not only shaped by interaction of students with lecturers in class or workshops. The curricular contents should be aligned to ensure students have enough stamina to excel the courses. The coordination across the school/division chairpersons and the facility administrators should be developed to ensure resources and facilities were available in time and in proper quality.

Throughout the first year of IED implementation, many learning materials have been gathered. These are to develop more structured and integrated learning plan in 2014-2015 academic year. The integration may cover the whole phase of engineering design at the first few weeks of the first semester and followed by the theories of design challenges and small group experiments for the rest of semester. The second semester therefore can be focused on all three-design challenges. The students of FIT, SLS and SP can be combined in groups and classes to instill the societal context of engineering design.

\section{Conclusion}

The angklung challenge has produced new understanding of how a course should be designed, planned, implemented and evaluated to achieve certain student outcomes. During the 2013-2014 academic year, the aspect of teamwork, experimental and communication skills were met along with the scientific comprehensions and design abilities. More work was still required to introduce the societal context of the engineering development to these first year undergraduate students. This shall be realized by more integrated learning plan, more synergy across lecturers, school/division leaders as well as facility leaders and better evaluation tools in 2014-2015 academic year.

\section{Acknowledgements}

The authors would like to thank Mr. H. E. Handiman Diratmasasmita of Bale Angklung Bandung for his valuable teaching, discussions, and supports in developing learning materials that made this course possible. The authors also thank Keluarga Paduan Angklung (KPA) ITB for their valuable support in tutoring the workshops.

\section{References}

[1] E. Redish, and K. Smith, "Looking beyond content: skill development for engineers", Journal of Engineering Education, vol. 97 (3), pp. 295-307, July 2008

[2] ABET Engineering Accreditation Commission, "Criteria for accrediting engineering programs: effective for reviews during the 2014-2015 accreditation cycle", ABET, Baltimore, USA, 2013.

[3] Peraturan Presiden Republik Indonesia No. 8 / 2012 tentang Kerangka Kualifikasi Nasional Indonesia (in Bahasa Indonesia)

[4] C. Atman, et al., "Enabling engineering student success: the final report for the Center for the Advancement of Engineering Education", San Rafael, CA: Morgan \& Claypool Publishers, 2010

[5] S. Y. Akbar, "Sejarah angklung dan perkembangan industri angklung di Indonesia"(in Bahasa Indonesia), Workshop Temu Karya KUKM dalam peningkatan standard mutu dan HKI angklung Indonesia, Saung Angklung Ujo, Bandung, October 2008.

[6] E. M. Budi, "Pengembangan robot angklung dengan rekayasa sistem tekno-sosial"'(in Bahasa Indonesia), Ph.D. Disertation, Institut Teknologi Bandung, July 2014.

[7] H. E. Diratmasasmita, "Metoda dan standarisasi pembuatan angklung"(in Bahasa Indonesia), Workshop Temu Karya KUKM dalam peningkatan standard mutu dan HKI angklung Indonesia, Saung Angklung Ujo, Bandung, October 2008. 